\title{
Teil 5 Übergangs- und Schlussvorschriften
}

\section{$\S 57$ Übergangsvorschrift}

Diese Verordnung ist nicht auf Grundleistungen anzuwenden, die vor ihrem Inkrafttreten vertraglich vereinbart wurden; insoweit bleiben die bisherigen Vorschriften anwendbar.

\section{$\S 58$ Inkrafttreten, Außerkrafttreten}

Diese Verordnung tritt am Tag nach der Verkündung in Kraft. Gleichzeitig tritt die Honorarordnung für Architekten und Ingenieure vom 11. August 2009 (BGB1. I S. 2732) außer Kraft. 